University for Business and Technology in Kosovo

UBT Knowledge Center

UBT International Conference

2015 UBT International Conference

Nov 7th, 9:00 AM - 5:00 PM

\title{
Rethinking Innovation - Contextual factors impact
}

\author{
Manuela Mece \\ Metropolitan University of Tirana, manuela.mece@gmail.com \\ Entela Lako \\ Metropolitan University of Tirana, entela.lako@undp.org
}

Follow this and additional works at: https://knowledgecenter.ubt-uni.net/conference

Part of the Business Commons

\section{Recommended Citation \\ Mece, Manuela and Lako, Entela, "Rethinking Innovation - Contextual factors impact" (2015). UBT International Conference. 25.}

https://knowledgecenter.ubt-uni.net/conference/2015/all-events/25

This Event is brought to you for free and open access by the Publication and Journals at UBT Knowledge Center. It has been accepted for inclusion in UBT International Conference by an authorized administrator of UBT Knowledge Center. For more information, please contact knowledge.center@ubt-uni.net. 


\title{
Rethinking Innovation - Contextual factors impact
}

\author{
Manuela Mece ${ }^{1}$, Entela Lako² \\ ${ }^{1,2}$ Metropolitan Univeristy of Tirana, UNDP Office Tirana. \\ manuela.mece@gmail.com ${ }^{1}$, entela.lako@undp.org ${ }^{2}$
}

\begin{abstract}
In the past 2 decades a keen interest in innovation is demonstrated by governments (financial instruments for R\&D) or intergovernmental agencies (EU financial instruments) because of its connection to regional economic advantage. In Albania, understandings of innovation is predominantly technological and product driven and defined in general terms such that the nature of innovation is disclosed of its contextual influence. Following the above logic innovation is assumed to be overly masculine. Through combined analysis of interview material from previous studies on the engendering of entrepreneurship based in Albania, this paper challenges current conceptualizations of innovation geographically and in a gender context. I will tend to present how the context, both social and geographical, of an innovation is elementary to its identification as innovative and moreover, reveal some of the many instances of innovation that occur in economic sectors and by agents that are typically ignored or undervalued by current factors of research and policy making. The analysis will aim to expand the concept of innovation for researchers and policymakers considering the concepts of regional development beyond those processes associated with technologically defined and growth-oriented sectors.
\end{abstract}

Keywords: Contextual Innovation, Innovation Property, Variables of Innovation, Genderised Innovation

\section{Introduction}

Innovation is widely seen as the key to regional and local economic advantage (Barkham, 1992; Chandra and MacPherson, 1994; MacPherson, 1992; Simmie, 1998; Suarez-Villa, 1991). Every region demonstrates a variable innovative capacity which shape in a way its economic destiny: those regions that have developed a competitive advantage (natural \& human resources or technology), or have attracted and supported innovative capacities will prosper; those that cannot will languish (Amin and Wilkinson, 1999; Helmsing, 2001; Keeble et al, 1999). Empirical studies document how innovative activities cluster in space and seek to explain why some places are more innovative than others and how, in turn, economic growth is related to innovative milieu (Feldman, 2000). Probably the most inclusive definition of innovation is that it is "the creation and exploitation of new ideas" (Kanter, 2000). More economically specific is Feldman's definition that emphasizes the links between capitalism and the competitive edge that innovation confers: "Innovation ... is the novel application of economically valuable knowledge" (2000). These scholarly definitions of innovation imply quite a broad terms (as they do not mention if the innovations engage technology or markets), economists in Western developed societies usually use the term 'innovation' to mean 'technological innovation' and in their empirical work are more concerned with manufacturing activities [Nijkamp et al (1997) and a few others include the business services sector too].

In fact, the theoretical concept of innovation has been developed referring to a limited range of economic activity - mostly those associated with use of a certain level of technology) thus excluding other sorts of economic activities, especially in labor intensive sectors or regions where the technology has limited sources to advance. A blunt conclusion will be that those economic sectors predominantly populated by men in terms of ownership and employment are the ones that fall comfortably within these dominant definitions of innovation. Current understandings of innovation reflect, moreover, the concept's origins in and linkages to a particular historical context, namely that of the $20^{\text {th }}$ century industrial complex that characterizes OECD countries. 
For at least the past decades, technological innovations in the telecommunication, automotive and manufacturing sector, have been the driving locomotive of economic development and wealth creation.

\subsection{Innovation "Property"}

As Innovation implies scientific knowledge, governments feel the obligation and responsibility to disperse it as the knowledge has certain "public" properties. Following this logic, the governments go further and finance the innovations. But the transaction goes beyond the Social Responsibility of the government for the dissemination of knowledge and the usefulness of the innovation. Government sponsored innovations has been instrumental to the creation of whole new industries and many innovations within existing industries. The Internet and the WEB, both tenets of the information superhighway that gave birth to thousands different companies all over the world grow out of government sponsored research (Afuah, 2003). In financing innovation, governments (those of western developed countries) accomplishes education objectives for part of the workforce, spurs private ventures to invest in related invention or commercialization activities and last but not least innovation projects can enjoy the economies of scale that come with large innovative projects.

My own research (empirical) of entrepreneurial ventures in Albania, specifically those emerging from women groups, have raised some questions in front of me to rethink innovation and its perception in geographic and gender context. Many of the entrepreneurs I have met in the course of my life, as a development professional, trainer or consultant, particularly but not exclusively women, saw their businesses as innovative in the sense that they brought economically viable, new ideas to a place and created significant positive change in that place - and above all they created the Margin to take the Risk for starting the venture. In other words, they were capable to identify and satisfy an unmet need. However, various scholars and policy makers (national government or intergovernmental agencies) in who shape local economic development (LED) policies would exclude these businesses from the category 'innovative' because these businesses serve primarily to local markets, or they do not employ a well-defined workforce - in terms of skills/profiles and because they hardly use any new technology. The broad definitions of innovation like those of Kanter and Feldman can introduce ambiguity such that it becomes difficult to know what is and what is not innovative. Referring to the even broader definition that innovation usually means Change both in the organizational and economic sense any model that seek to understand the phenomenon (cause of Change) is multidisciplinary (Afuah, 2003). Additionally innovation entails dealing with new knowledge - collecting information and turning it into new products or services, which are undoubtedly the core activities of many small businesses taking place in rural areas or small towns.

\subsection{Variables of Innovations}

Rethinking innovation in a way requires exploring further 2 variables place and the social identity of the innovator patterns - what can count as innovation and therefore what commands the attention of policymakers. The main aim of several developing professionals and agencies as well as my intention is to take into consideration and give credits to the contributions and transformative roles of a greater range of businesses and business owners. By recognizing these activities as innovations policy makers can go beyond simple acceptance to quick alterations in approaches to local and regional economic development. The potential of context for revealing innovation and innovative opportunity can be related to geography and gender by real life cases. Examples from economic initiatives in Albania and SME studies illustrate how contextualizing innovation geographically and socially makes visible previously unrecognized opportunities for innovation. The paper draws conclusions about the implications of rethinking innovation for incorporating a more inclusive and contextualized understanding of innovation in local and regional economic development policy. Rethinking innovation seems particularly important now, in light of recent changes in gender and economic development models. Feldman (2000) and Afuah 2003 notes two dimensions of innovations - product versus process innovations and incremental versus radical. Product innovation is the creation of new products, which can be empirically measured through patents or new product presented whereas process innovations concern the ways that businesses understand, organize, or motivate change that will lead, according to Pavitt (2003), "to competitive success". Following this argument, by their very nature process innovations are very difficult to be measured. Incremental innovations concern small 
improvements or changes, whereas radical innovations create entirely new products or categories of products and require new competencies. These competencies are usually defined in terms of the labour inputs, and the literature points to the importance of information exchange in facilitating this aspect of innovation (for example, Lawson and Lorenz, 1999; Massey et al, 1992). Product and process innovations may be either incremental or radical. If we use the category of product innovation as an example, a radical innovation may replace an existing product or category (for example, the automobile replacing the horse as a dominant mode of transportation) or it may introduce something entirely new into the marketplace. Process innovations are similarly radical or incremental, but difficulties in identifying process innovations are enlarged when one is trying to determine degree of innovation. Although the link between innovation and technology is not a necessary one, in practice current conceptions concerning both process and product innovations in the empirical literature are most often taken to mean some form of technological change - either in a product or in the production of a good or service (for example, Kanter, 2000; Keeble, 1997; Simmie, 2002). Indeed, although Bunnell and Coe (2001) and Amin and Thrift (1997) each struggle to describe a broad theoretical conception of innovation, one that encompasses more than just technological innovation, their review of empirical works highlights the main focus on technological change in recent research. Innovations out of technology driven sectors, although tangled in the definitions of innovation that they use, are not illustrated or discussed. Government and quasi-government agencies concerned with innovationfocused economic development as well focus on technological innovations - neglecting other forms of innovative activity - in their efforts to increase local wealth.

Various scholars have placed particular emphasis on the ways that local knowledge and social networks can enable access to resources within a specific location for those who are perceived to be innovators (for example, Amin, 1999; Amin and Thrift, 1997; Harrison, 1994; MacLeod, 1998; Maillat and Lecoq, 1992; Pamuk, 2000). Places that are 'institutionally thick' supposingly have an abundance of resources, with a distribution system characterized by coordinated and well-defined institutional structures (Amin and Thrift, 1994). Thus, local legal framework as well as the cooperation among actors within a particular business community, shapes the distribution of capital and information to innovators and from innovators to the market.

In developing societies (but not only) there is no real attempt to understand how innovation happens in the first instance or how the demand for and supply of innovations is studied in its context. In many societies, innovative products and those who create them are without a theoretical identity. Explaining the relation between commodities and geographic areas Molotch (2002) suggests a way forward by arguing that goods are mirrors of the location in which they are produced. He clarifies through the use of examples (including the configurations of and geographical variations in the design and marketing of toilets, condoms, and garlic presses) that products emerge in particular ways because of the norms, rules, expectations, and facilities that exist in the place. Molotch's products, however, seem to be developed when and wherever there is an acknowledged demand (market). Molotch does not consider the role of the innovator and his/her position in affecting the occurrence of particular innovations. Thus the argument follows that innovations themselves are not just products of place, but also of the people who are resources (human) identified in that region/place. Innovations occur from the interaction of place and the human factor (identity and social positioning) of the innovation and the innovator. A clever businessman/woman may detect an existing need in the market place, he/she can even incite a need (smartphones versus cell phones) but who perceive a way to satisfy that need (who innovates) affects the ability of that innovation to come into being and this process is place specific. Kanter (2000) compares innovations to flowers and argues that like seeds, innovations must be nurtured carefully in order to thrive. In Kanter's metaphor, garden conditions are as important as the gardener for flowers to blossom. By extending the metaphor the garden and its design (and by implication the gardener) can assist in determining the value of individual plants. What is harmful to one gardener or in one garden may be considered a hint. Thus, innovations do not simply thrive or fail depending on the resources available within particular contexts as Kanter suggests; it is the value that is attached to (nascent) innovations - value that depends on geographical context - that determines whether an economic activity will be seen as innovative and nurtured accordingly or neglected as useless. In this way, innovations are very much embedded in the geography. Lash and Urry (1994) and then Lee (2002) argue that commodities represent as much significance from their symbolic content as from their material content and that this symbolic content is linked to the workings of everyday life and gives rise to what Lee (2002, page 336) refers to as the "materiality of economies". Thus the meaning of innovations "make[s] sense in material terms only in the context of 
circuits of material reproduction" (page 336). The context of these circuits includes the spatially defined supply-and-demand relationship but also spatially defined social relationships (see also Molotch, 2002). The circuits of material reproduction associated with male-dominated industries and more generally with entrepreneurship and business ownership are embedded in gender regimes that historically have excluded women (Mirchandani, 1999). By challenging and undermining the material associations between men and auto repair, construction, or even 'executive functions', women who enter male-dominated economic spheres are fundamentally changing the material, social, and political landscapes of material reproduction and thereby creating new economic geographies in very innovative ways (Hanson and Blake, 2005). My point is that the symbolic and material assumed values for a potential innovation depend on the interchange between place and ways of interactions amongst the innovator and the innovation and the location where it happens.

\subsection{Women and Innovation}

Women are socially located within places differently from men (McDowell, 1997), including the place-specific ways that women are positioned in relation to business ownership; however they are likely to be important in creating opportunities (market demands) for innovations and in determining their values. The contextualizing of innovation - making what is considered innovative dependent on context - calls for raising hypothesis that innovations need a specific place, rather than accepting a universal norm and it also calls for a new way of thinking about how innovative activity relates to context. Specifically, it highlights the role of the social and economic environment in valuing and promoting certain kinds of innovative activity while devaluing and even actively discouraging others (Blake 2004). A contextualized innovation acknowledges that innovators are an undisputed part of the location and therefore naturally related to local contexts for innovation in distinctive ways. The social identities of innovators shape the patterns that certain institutions in a particular context promote, value, and define innovations. In this perspective gender is thoroughly associated to the how and why certain geographic contexts encourage some kinds of innovations to emerge and develop while discouraging or preventing others.

\section{Developing innovation}

Embracing a notion of innovation that is related and inspired by the location and that does not necessarily highlight technology over all else requires an understanding of economic development and related initiatives that differs from those that currently seek to promote innovation. Indeed, as a development professional I support LED that seeks to develop people and places more generally, rather than advancing a neoliberal, capitalist development agenda (Gibson-Graham, 1994). The majority of LED approaches have focused on innovation, traditionally understood, as part of their remit to position the local economy advantageously within a global, neoliberal project (for a related discussion see Sheppard, 2002).

Examples include science parks and innovation centers designed to create the conditions that existed in Silicon Valley in USA or the Cambridge in UK. The success of these initiatives has been evaluated on their ability to create new fast growing businesses so as to expand the competitive advantage of and generate a privileged status for the regions in which they are located; but not in terms of improved potentials for redistributing wealth or improved social well-being of this specific place. In fact, other approaches to LED have been suggested and implemented though not explicitly linked to innovation. LED initiatives usually tend to meet local needs and the transformative power of these initiatives could be enhanced by the kind of reconsidering innovation. Specifically, LED efforts would benefit from a perception of innovation process that is sensitive to where the innovation is taking place and who the innovator is. Alternative approaches to LED (those that focus on local well-being broadly construed) are consonant with recent thinking in the urban planning literature on what makes good cities. Although, as Fainstein (1999) notes, some authors emphasize outcomes (the substance of the good city) whereas others emphasize process (the planning and political processes that constitute the good city), all stress the importance of the inclusion of marginalized groups. I hope that the argument about innovation contributes to this literature by specifying how the positionality of certain citizens affects their ability to enhance local economic development and hence to contribute to creating 'the 
good places.' The broader definition of innovation supported in this article is embedded within a concept of LED that embraces the needs and contributions of all people.

\section{Placing innovation}

Before discussing in the next section a few examples of contextualized innovations, I briefly describe the empirical projects from which these examples are drawn. The research focused on women business owners in Diber region, Vlore and Korce, with particular attention to how gender and geographical location area influenced a woman's ability to access resources for her business. The research involved interviews with ten women business owners initially supported by Aid developing funds like, Oxfam GB, UNDP, SNV, SDC, other stakeholders like governmental agencies and international donors. This paper is the first research focusing on the intersection of gender and geography in entrepreneurship, with particular attention to how gender shapes the start-up process, location decisions, and the relationship of the business to place.

Aldrich and Waldinger (1990) provide a definition of entrepreneurship as "the combining of resources in novel ways so as to create something of value." New firms and small firms are often considered more innovative than older and larger existing firms (Acs et al, 1999; Aoyama and Teitz, 1996; Barkham et al, 1996; Brown et al, 1990; Siegel, 1990) and the number of new firm start-ups in a place has been used as an indicator of innovative activity (for example, Audretsch and Vivarelli, 1994). Moreover, the use of numbers of start-ups to measure regional or local innovative activity is just one illustration of the frequently made correlations between innovation and entrepreneurship. The connection between small/new businesses and innovation is neither strong nor exclusive. Although not all small or new firms are necessarily innovative studies of non-franchised business owners of small and medium-sized firms disclose many of them who combine resources in 'novel' ways to meet needs that were unrecognized and that are attentive to innovative activity occurring in sectors not typically associated with technology. The examples of innovative activity described below appeared primarily in answering to questions about the nature of the business and the contribution that the business owner felt that their business made, if any, to their community - "What do you see as innovative about your business?" Qualitative analysis sanctions the complexity of the relationships between context and gender in innovation, an advantage that seems relevant in exploring the reconceptualized understanding of innovation that was outline above.

\section{Identifying innovation}

Only a small minority of the business owners replied that they saw nothing at all innovative about their businesses. Respondents' comments about the nature and contributions of their businesses centered largely on what the owners saw as new or unique in what they were providing to the market (that is, in what ways they were not simply replicating an existing service or product). The fact that these business owners see themselves as innovative or providing something new or different to the market is important because it illustrates the wide range of innovative activity that can occur in places and in sectors not traditionally recognized as innovation potentials. Rather than providing an exhaustive list of the innovations that were identified, I will focus the remaining discussion on two important and interconnected themes that illustrate the roles of geographical and social context in defining these innovations.

The first concerns the importance of place: we found that local context and local scale linked closely to innovation; innovations happen somewhere and are delivered to specific markets, whether few or many buyers and sellers inhabit these markets. Place is, therefore, inextricably linked to the form innovations take as they enter the market as well as the process through which an innovation occurs. The second theme is that a person's social identity and personal experiences are a rich source of innovations that have the capacity to change the landscape of material reproduction fundamentally. The gender examples focus on women and the role that gender plays in fixing their positionality and shaping their experience. This is not to say that innovations cannot also come out of the unique circumstances of male positionality and experience or that other forms of social identity are not also likely to create opportunities for innovation. 


\subsection{Places of innovation}

The most common advice to the would-be entrepreneur is to identify a need and fill it. The unarticulated part of this aphorism is that most needs are defined spatially (in a specific location); properly revised, the adage should be, 'Find a need somewhere and fill it there.' Innovations that provide services or products that are new to 'here' meet particular needs that are defined by the circumstances of a place. I started with a social business that provides Jufka (local form of noodles) in Diber one that produces Olive Paste in Vlore and a handicraft unit producing embroideries in Korce region. In each case the innovator used local knowledge (that is, that a certain product was absent and needed 'here') to exploit a spatial niche. The first example involves a group of 14 women aged from 30 to 60 years-old man whose expertise in producing Jufka comes from their own kitchen. Oxfam GB assisted them to perceive the market demand for traditional food and accompanied them step by step to conceptualize their own enterprise. Oxfam assistance consisted in financial and technical support. In the second example, a group of 10 women aged 27 to 55-years-old that are growing olive trees for oil production in Novosele identified a niche market demand for Olive Paste. The group was assisted from UNDP and a local NGO to develop the idea into an economic initiative. The last example is the group of embroiders and wavers of Erseke (Korce region) aiming a forming a social business (trading cooperative) that will reinvent their traditional patterns of embroideries and kilims.

Being the first to bring a product or service to a place seems, however, to fit the definitions of innovation mentioned at the outset: "the creation and exploitation of new ideas" (Kanter, 2000, page 168 ) and "the novel application of (not just) economically valuable knowledge" (Feldman, 2000, page 373). In each of our three examples, the economically valuable knowledge was the entrepreneur's familiarity with place, which enabled the accomplishment that there was a particular need to be filled 'here'. All three of these businesses contribute in important ways to the quality of life in their own locations. Other such innovations include a medicinal and wild teas collection unit in Burrel that sells in wholesaling and retailing markets, a nursery greenhouse for women farmers that grow vegetables in Kastriot (Diber) and a technical assistance unit for orchard farmers in Korce and Diber. These businesses all fill some place-specific local need where local may refer to the scale of a city, a neighborhood and so on. Moreover, these examples are not merely innovation diffusion, as their innovation involves recognizing the place-specific need in the first instance and then developing a solution to that need. In the above examples the business owners are co-local to their customer base. Many of the business owners contacted highlighted as innovative about their business - the responsiveness to the local market, not to some generic market. Often this comment was followed by certain remarks about the large, chain, 'big box' stores, which are seen as catering only to a generic market. These business owners recognize that business interactions are context dependent and in order to increase the value of their product or service and thereby offer something that is unique they must think geographically.

\subsection{Gendered innovation}

The associations between embodiment and definitions of skilled work and between embodiment and the allocation of jobs result in striking gender differences in women's and men's labour-market profiles (Hanson and Pratt, 1995; Jensen, 1989; McDowell, 1997). Certain economic activities emerge as innovative specifically from an entrepreneur's embodiment because with embodiment comes position and experience that is tempered by the individual's social identity. Positions mean that some individuals, because of their identities, are seen as legitimate members of a group whereas others are not (McDowell, 1997). Furthermore, individuals experience the world through these positions of identity: The experiences of men are different from those of women. Here the focus goes on two gendered aspects of innovation: in the first, the entrepreneur launches a gender atypical business, and in the second the entrepreneur's experiences as a woman led her to promulgate innovative organization strategies. Individually, innovations like the ones described may not lead to a sea change in the social order. 


\subsubsection{Women in gender-atypical businesses}

Through the act of owning a business in a male-dominated industry, such as trucking, construction, or auto repair, women entrepreneurs can become innovators. Owning a gender-atypical business is innovative because the owner does not conform to an assigned gendered position. Although the discussion centers on examples of women, the point holds true both for women and for men. Women business owners who seek to act as role models and to act out their atypical role successfully must overcome their illegitimate status. The women in my studies that did this most successfully exploited traditional understandings of gender to advance their enterprises. To illustrate this point I draw from the examples a woman-owned medicinal collection unit. A 52-year-old woman told that perhaps the main barrier women face in gaining access to this difficult market is the difficulty of obtaining the appropriate network. Although the institutionalized way that skills for the trades are constructed seems to limit women's involvement in this economic sector, the widespread perception of tradesmen as 'cowboys' who are unreliable, dishonest, and sometimes unskilled and the fact that these perceptions do not apply to women provides an opening for women in the field. This entrepreneur saw that she was able to build on feminine associations of trust, cleanliness, reliability, and an interest in making the customer understand what she was doing to overcome the barriers she faced as a woman working in a male-dominated field in which businesses are typically perceived as not being concerned with such issues. By building on customers' perceptions of femininity, which in many ways are more positive than are prevailing perceptions of men in the trades, and by performing her task in a way traditionally associated with the feminine, she uses those identity-based resources to which she has access to offer a novel service. The existence of these successful businesses with women obviously performing gender atypical roles should enable future ventures by women in non-traditional industries to acquire the start-up bank loans that these women were not easily provided. In fact, contra the bankers' worries that women-owned businesses in these fields would not attract customers because customers would not see them as legitimate, the embodied nature of these innovations has proven to be a competitive advantage, enabling these business owners to capture market share in industries that are typically considered highly competitive. Moreover, by introducing trust and cleanliness into their economic sectors, these women entrepreneurs have fundamentally altered the way business is done in these sectors. When, however, the market does not know that such a firm is woman owned the innovative potential is muted.

\subsubsection{Gendered experience}

The previous examples describe how gender helps to define certain products as innovative. Because business ownership is culturally coded as male, the traditional model of management that is most widely used and taught in business schools is a masculine model (for a discussion see Boot, 1994; Swan, 1994) . By incorporating ways of managing people that are learned in arenas that are often associated with women's work, such as the home, or are not typically considered management oriented, such as mothering, women are introducing process innovations into management. These innovations are not necessarily rooted in technology, as was the introduction of Ford's assembly line for example. A lawyer who also owns a beauty center spoke specifically about what she described as the "mommy model" of running a business and offered some insights into the ways she has innovated in the treatment of her staff. This business owner sees the "mommy model" as a network of relationships rather than a hierarchy: "The mommy model works with the strengths and weaknesses of individuals rather than making individuals conform to a single ideal. This model is goal oriented rather than power oriented, meaning that the manager talks through problems rather than issuing information and is willing to shift hats rather than putting people in dedicated tasks. This type of manager will also take a back seat when necessary and does not always need to be the central figure. This type of manager tries to find out the strengths and weaknesses of everyone and bring all the staff along with them." This woman gave examples of how she practices this form of management, one of which was how she was able to work with the existing strengths of an older employee with a good understanding of face massaging to overcome her fear of the new pealing techniques.

In concluding this section on identifying innovation, we highlight two points. The first is that the local scale has a close relationship with innovation. For some entrepreneurs, capturing the place-specific nature of a market enables them to create a successful business whereas for others the social conditions within a place enable the initial introduction of the innovation. These place-inspired and place-based 
innovations produce a new service or product that enhances the economic well-being and quality of life in that place. The second point is that, although the innovations described do not directly add to regional exports in the traditional sense, they are all associated with profitable small businesses and they all exemplify outcomes that would not be considered innovative under prevailing definitions of the term. Moreover, the contributions of these business owners could be accepted as innovative if researchers and policymakers concerned with innovation were to pay more attention to the geographical and social location or context of economic activities.

\section{Implications for research}

In order to understand better how innovation contributes to the welfare of places, researchers need to broaden the scope of contexts, economic sectors, and actors that they consider as potential sites and creators of innovation. Research that aims to comprehend the full spectrum of innovation should include geographic contexts that are not necessarily characterized by an orientation toward technology. Through a few empirical examples, above, the issue that context locates opportunities for innovation are highlighted. By capitalizing on their geographical and social contexts, some entrepreneurs are able to contribute to their communities in various ways currently unacknowledged and unappreciated by the exporters or other stakeholders. These contributions include satisfying genuine needs in the community, offering improved working conditions for employees, creating new employment opportunities for marginal groups, developing skills, and generating social cohesion. Because these contributions are extremely important to the economic and social well-being of the regions, and in order to understand the relationship between innovation and context, research should seek explicitly to study all or more economic sectors. Recognizing that innovations can occur in any place and in any economic sector should mean recognizing that innovators come in various forms of personification. Because of gender-based, age-based, and race-based divisions in the labor market, there is a strong relationship between social context and certain economic sectors of innovation. Women, for example, are more likely to start businesses -and therefore more likely to innovate - in retail and service industries than in other sectors. Research needs to explore the processes that link social identity, geographic context, and innovation in order to appreciate fully how innovation affects places

\section{Questions for policymakers}

Because research and policy are so closely linked, rethinking innovation has important implications not only for research but also for local and regional economic development policy. Current Local Economic Development practice gives substantial attention to attracting employers from elsewhere rather than to enhancing the innovative potential of resident entrepreneurs, especially those whose innovations would ostensibly serve only the local market (Raco, 2000). In view of recent shifts in economic regimes (for example, the decline in manufacturing and rise in services), the question is whether this export-oriented focus is really the right way. Prioritizing growth-oriented profits through technology rather than valuing, for example, equity or community well-being means that Local Economic Development policies aimed at attracting and fostering innovation also reinforces divisions within the labor market. These divisions are reinforced through the ways that resources are allocated (Clarke and Newman, 1997; Edwards, 2002). The current perceived association between innovation and export sales leads to resources being channeled to a few firms in economic sectors where there are high rates of social division in the labor market. The majority of organizations that create jobs for workers in a place (for example, nonprofit organizations, government, local businesses) are not participating in the pursuit of export profits. Yet dominant Local Economic Development policy approaches overlook these employment-rich economic activities and end up channeling resources away from certain social groups, like women. 


\section{References}

1. Afuah A, "Innovation Management: strategies, implementations and profit" Oxford University Press, ISBN-13 978-0-19-514230-3

2. Amin A, 1999, "An institutionalized perspective on regional economic development" International Journal of Urban and Regional Research 23365 - 378

3. Aslanbeigui N, Summerfield G, 2001, "Risk, gender, and development in the 21 st century" International Journal of Politics, Culture, and Society 157 - 26

4. Bunnell T, Coe N, 2001, "Spaces and scales of innovation" Progress in Human Geography 25 $569-589$

5. Edwards C, 2002, "Barriers to involvement: the disconnected worlds of disability and regeneration" Local Economy 17123 - 135

6. Feldman M, 2000,'Location and innovation: the new economic geography of innovation, spillovers, and agglomeration", in The Oxford Handbook of Economic Geography Eds M Feldman, G Clark, M Gertler (Oxford University Press) pp 373 - 94

7. Hanson S, 2003 Geography, Gender, and the Workaday World: Hettner Lectures number 6 (Franz Steiner, Stuttgart)

8. Hanson S, Blake M, 2005, "Changing the gender of entrepreneurship", in A Companion to Feminist Geography Eds L Nelson, J Seager (Blackwell, Oxford) pp 179 - 193

9. Hanson S, Pratt G, 1995 Gender, Work, and Space (Routledge, London)

10. Harrison B, 1994 Lean and Mean: The Changing Landscape of Corporate Power in the Age of Flexibility (Basic Books, New York)

11. Irwin S, Bottero W, 2000, "Market returns? Gender and theories of change in employment relations" British Journal of Sociology 51261 - 280

12. Kanter R M, 2000, "When a thousand flowers bloom: structural, collective and social conditions for innovation in organization", in Entrepreneurship Ed. R Swedberg (Oxford University Press, Oxford) pp $167-210$

13. Lawson C, Lorenz E, 1999, "Collective learning, tacit knowledge and regional innovative capacity" Regional Studies 33305 - 317

14. McDowell L, 1997 Capital Culture: Gender at Work in the City (Blackwell, Oxford)

15. Malecki E J, 1994, "Entrepreneurship in regional and local development" International Regional Science Review 16119 - 153

16. Mirchandani K, 1999, "Feminist insight on gendered work: new directions in research on women and entrepreneurship" Gender, Work and Organization 6224 - 235

17. Molotch H, 2002, "Place in product" International Journal of Urban and Regional Research 26 $665-688$

18. Pavitt K, 2003, “The process of innovation", Science and Technology Policy Research Electronic Working Paper Series, The Freeman Centre, University of Sussex, Brighton, http://www.sussex.ac.uk/spru/publications/imprint/sewps/sewp89/sewp89.html

19. Porter M E, 1990 The Competitive Advantage of Nations (Free Press, New York) Raco M, 2000, "Assessing community participation in local economic development-lessons for the new urban policy" Political Geography $19573-600$

20. Sheppard E, 2002, "The spaces and times of globalization: place, scale, networks, and positionality" Economic Geography 78307 - 330

21. Siegel B, 1990, "Business creation and local economic development: why entrepreneurship should be encouraged", in Enterprising Women: Local Initiatives for Job Creation (OECD, Paris) pp $11-20$

22. Simmie J, Sennett J,Wood P, Hart D, 2002, "Innovation in Europe: a tale of networks, knowledge and trade in five cities" Regional Studies 3647 - 64

23. Suarez-Villa L, 1991, "Regional evolution and entrepreneurship: roles, eras and the space economy" Entrepreneurship and Regional Development 3335 - 347

24. Swan E, 1994, "Managing emotion", in Women in Management Ed. M Tanton (Routledge, London) pp $89-109$ 